Venture Capital, Islamic Finance and SMEs 
This page intentionally left blank 


\section{Venture Capital, Islamic Finance and SMEs}

Valuation, Structuring and Monitoring Practices in India

Mansoor Durrani and Grahame Boocock 


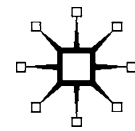

(C) Mansoor Durrani and Grahame Boocock 2006

Softcover reprint of the hardcover 1st edition 2006 978-1-4039-3638-7

All rights reserved. No reproduction, copy or transmission of this publication may be made without written permission.

No paragraph of this publication may be reproduced, copied or transmitted save with written permission or in accordance with the provisions of the Copyright, Designs and Patents Act 1988, or under the terms of any licence permitting limited copying issued by the Copyright Licensing Agency, 90 Tottenham Court Road, London W1T 4LP.

Any person who does any unauthorized act in relation to this publication may be liable to criminal prosecution and civil claims for damages.

The authors have asserted their rights to be identified as the authors of this work in accordance with the Copyright, Designs and Patents Act 1988.

First published 2006 by

\section{PALGRAVE MACMILLAN}

Houndmills, Basingstoke, Hampshire RG21 6XS and

175 Fifth Avenue, New York, N. Y. 10010

Companies and representatives throughout the world

PALGRAVE MACMILLAN is the global academic imprint of the Palgrave Macmillan division of St. Martin's Press, LLC and of Palgrave Macmillan Ltd. Macmillan ${ }^{\circledR}$ is a registered trademark in the United States, United Kingdom and other countries. Palgrave is a registered trademark in the European Union and other countries.

ISBN 978-1-349-51855-5

DOI 10.1057/9780230626256

ISBN 978-0-230-62625-6 (eBook)

This book is printed on paper suitable for recycling and made from fully managed and sustained forest sources.

A catalogue record for this book is available from the British Library.

Library of Congress Cataloging-in-Publication Data

Durrani, Mansoor, 1965-

Venture capital, Islamic finance and SMEs : valuation, structuring and monitoring practices in India / Mansoor Durrani and Grahame Boocock. p. $\mathrm{cm}$.

Includes bibliographical references and index.

1. Venture capital-India. 2. Small business-Finance-India. 3. FinanceIslamic countries. 4. Finance-Religious aspects-Islam. I. Boocock, Grahame, 1952- II. Title.

HG5738.D87 2006

$332^{\prime} .094154^{\prime} 0954-d c 22$

2005051548

$\begin{array}{rrrrrrrrrr}10 & 9 & 8 & 7 & 6 & 5 & 4 & 3 & 2 & 1 \\ 15 & 14 & 13 & 12 & 11 & 10 & 09 & 08 & 07 & 06\end{array}$


Success comes only from Allah, the Mighty, the Wise (Qur'an, 3: 126)

To those who strive to establish a just and fair economic order.

Mansoor Durrani

To Clare, Chris and Alex for their patience and understanding. Grahame Boocock 
This page intentionally left blank 


\section{Contents}

List of Tables $\quad$ xi

List of Figures xii

Preface xiii

Currency Exchange Rates xiv

Glossary $\quad \mathrm{xV}$

$\begin{array}{lll}\text { Chapter } 1 & \text { Introduction } & 1\end{array}$

Chapter 2 An Introduction to the Small Business Sector 5

2.1 Introduction 5

2.2 The benefits of SMEs 7

2.2.1 SMEs: employment opportunities $\quad 7$

2.2.2 SMEs: flexibility and innovation 8

2.2.3 SMEs: internationalization 9

2.3 Characteristics of SMEs 11

2.4 Profiles of successful/unsuccessful SMEs 16

$\begin{array}{lll}2.5 & \text { Summary } & 19\end{array}$

Chapter 3 Barriers to Growth in SMEs 20

3.1 Introduction 20

3.2 Barriers to growth: finance-related 20

3.3 Non-financial barriers to growth 27

3.4 SMEs: a case for government support? $\quad 30$

3.5 Summary 33

Chapter 4 An Introduction to Venture Capital 35

4.1 Introduction 35

4.2 Definition of venture capital 36

4.3 History of venture capital 37

4.4 Evolution of contemporary venture capital $\quad 38$

4.5 The spectrum of venture capital 38

4.5.1 The venture capital institutions $\quad 39$

4.5.2 Formal venture capital 40

4.5.3 Corporate venture capital 41 
4.5.4 Social venture capital 42

4.5.5 Business angels 43

4.6 Venture capital in established markets 44

4.7 The dissemination of venture capital 45

4.8 The macroeconomic impact of venture capital $\quad 47$

$\begin{array}{lll}4.9 & \text { Summary } & 51\end{array}$

Chapter 5 Venture Capital: Theoretical Foundations for Research

5.1 Introduction 52

5.2 Theoretical foundations of research into venture capital $\quad 54$

5.2.1 Theory of the firm 54

5.2.2 The principal-agent relationship 54

5.2.3 Adverse selection 55

5.2.4 Theory of contracts 56

5.2.5 Corporate governance 58

5.2.6 Moral hazard 59

5.3 The venture capital investment process 59

$\begin{array}{lll}5.3 .1 & \text { Fund raising } & 60\end{array}$

5.3.2 Deal generation 61

5.3.3 Initial screening 62

5.3.4 Due diligence 62

$\begin{array}{lll}5.3 .5 & \text { Valuation } & 65\end{array}$

5.3.6 Approval and structuring 66

5.3.7 Monitoring 68

$\begin{array}{lll}5.3 .8 \text { Exit } & 70\end{array}$

$\begin{array}{lll}5.4 & \text { Summary } & 71\end{array}$

Chapter 6 An Introduction to India: The Economy, Financial System, SMEs and Venture Capital 72

6.1 Introduction 72

6.2 The Indian economy 72

$\begin{array}{lll}6.3 & \text { Financial system } & 77\end{array}$

6.4 SMEs in India 83

6.5 Venture capital in India 87

$\begin{array}{lll}6.5 .1 & \text { History } & 87\end{array}$

$\begin{array}{ll}\text { 6.5.2 Current position } & 92\end{array}$

6.5.3 Prospects 94

$\begin{array}{lll}6.6 & \text { Summary } & 97\end{array}$ 
Chapter 7 Venture Capital in India: The Analytical

Framework

98

$\begin{array}{lll}7.1 & \text { Introduction } & 98\end{array}$

7.2 Scope of the research 100

7.3 Research objectives 101

7.3.1 The characteristics of venture capital

$\begin{array}{lll}7.4 & \text { Risk management strategies } & 102\end{array}$

$\begin{array}{lll}7.4 .1 & \text { Valuation } & 102\end{array}$

7.4.1.1 Valuation information 103

7.4.1.2 Valuation techniques 105

$\begin{array}{lll}\text { 7.4.2 Structuring } & 107\end{array}$

7.4.2.1 Contractual covenants 108

7.4.2.2 Staging of investments 111

7.4.2.3 Choice of financial instruments 112

7.4.3 Monitoring 116

7.4.3.1 Monitoring mechanisms 116

7.4.3.2 Replacement of CEOs in investee companies 119

7.4.3.3 Reasons for replacement of CEOs $\quad 120$

$\begin{array}{lll}7.5 & \text { Summary } & 120\end{array}$

Chapter 8 Venture Capital in India: Research Methodology and Findings 122

8.1 Introduction 122

8.2 Descriptive profile of survey participants 124

8.3 Investigating the propositions 131

8.4 Conclusions 144

8.4.1 Valuation 144

$\begin{array}{lll}8.4 .2 & \text { Structuring } & 145\end{array}$

8.4.3 Monitoring 146

8.5 Summary 146

Chapter 9 Business Ethics and Venture Capital in Islam 148

9.1 Introduction 148

9.2 The adverse consequences of growth 149

9.3 An alternative view 150

9.4 Ethical principles in Islam 150

9.5 Business ethics in Islam 153

9.5.1 Ethical investments 153

9.5.2 Compliance with contracts 153 
9.5.3 Deceptive advertising and misrepresentation

9.5.4 Accurate measurement and weights

9.5.5 Hoarding and destruction of surplus produce

9.5.6 Fair recruitment practices 155

9.5.7 Human resource practices 155

9.5.8 Corporate governance 155

9.5.9 Environmental protection 156

9.5.10 Wealth distribution 156

9.5.11 Prohibition of interest 157

9.6 The differentiator 158

9.7 Venture capital and Islamic finance 159

9.8 Towards acceptable Islamic VC procedures 163

9.8.1 Valuation 164

$\begin{array}{lll}\text { 9.8.2 Structuring } & 165\end{array}$

9.9 Summary 168

Chapter 10 Conclusions 170

10.1 Introduction 170

10.2 Review of key themes 170

10.3 Key findings of the research programme 179

10.4 Islamic finance 181

10.5 Implications for policy makers, SMEs/ entrepreneurs, finance practitioners and academics

10.5.1 Policy makers 181

10.5.2 SMEs/entrepreneurs 188

10.5.3 Venture capitalists 189

10.5.4 Islamic finance 190

10.5.5 Academic researchers 191

Notes 193

References 196

$\begin{array}{ll}\text { Index } & 218\end{array}$ 


\section{List of Tables}

Table 4.1 Annual VC Investment in Asia

Table 6.1 Production, Employment and Exports in the Small Scale Sector

Table 6.2 Reasons for Closure of Small Businesses (2002 survey)

Table 6.3 Aggregate Venture Capital Investment in India

Table 8.1 Survey Participants

Table 8.2 Stage of Investments

Table 8.3 Sector of Investments

Table 8.4 Key Characteristics of VC firms

Table 8.5 Sources of Information for Valuation Purposes

Table 8.6 Valuation Techniques used by Venture Capitalists

Table 8.7 Qualitative Valuation Methods used by Venture Capitalists

Table 8.8 List of Structuring Covenants used in India

Table 8.9 Venture Capitalists' Preferences for the Staging of Investments

Table 8.10 Use of a Combination of Financial Products

Table 8.11 Monitoring Reports used by Venture Capitalists in India

Table 8.12 Percentage of CEOs Replaced by the Venture Capitalists

Table 8.13 Lack of Skills Responsible for the Dismissal of Investee CEOs

Table 9.1 Shari'ah View of Some Key Practices in Venture Capital Financing

Table 10.1 Summary of Key Findings 


\section{List of Figures}

Figure 4.1 Average Annual Returns on US Assets,

1945-1997 (\%) 48

Figure 5.1 The Venture Capital Investment Process 60

Figure 5.2 Information Factors used in VC Decision 63 


\section{Preface}

This book grew out of the PhD studies of Mansoor Durrani, the first doctoral research ever undertaken on the subject of VC in India. Whilst working on his thesis, Mansoor met Grahame Boocock, an academic with longstanding research interests in the areas of risk capital and the financing of small and medium-sized enterprises (SMEs). Grahame had previously spent a year at University Utara Malaysia. This book represents the fruits of their collaboration at Loughborough University, a highly rated University in the East Midlands of England.

Mansoor Durrani would like to acknowledge the assistance provided by the following individuals. Thanks are due to my PhD supervisor Professor John Presley for his invaluable comments and continued guidance throughout my doctoral studies. For Professor Khurshid Ahmad (Chairman, Markfield Institute of Higher Education, UK), I just do not have words to express my gratitude. May Allah reward him for his support, encouragement and guidance. I am also grateful for the contributions of Drs. Umer Chapra and Tariqullah Khan, both of Islamic Development Bank (Jeddah), in shaping Chapter 9.

Both authors wish to acknowledge the valuable contributions of Professor Mike Wright (Director, Centre for Management Buy-out Research: University of Nottingham), and Drs. Dave Coates and Neil Doherty (both lecturers at Loughborough University Business School).

A final debt of thanks should be expressed to members of the Indian venture capital industry who gave generously of their time, despite operating under the pressures of modern business! 


\section{Currency Exchange Rates}

\begin{tabular}{lccc} 
As at 31/12 & US\$/Indian Rupee & As at 31/12 & UKE/Indian Rupee \\
\hline 1994 & 31.37 & 1994 & 48.27 \\
1995 & 31.58 & 1995 & 48.62 \\
1996 & 35.60 & 1996 & 55.12 \\
1997 & 35.75 & 1997 & 57.49 \\
1998 & 43.16 & 1998 & 69.82 \\
1999 & 43.42 & 1999 & 69.46 \\
2000 & 45.90 & 2000 & 68.79 \\
2001 & 47.12 & 2001 & 68.04 \\
2002 & 48.55 & 2002 & 74.64 \\
2003 & 45.87 & 2003 & 73.11 \\
2004 & 46.31 & 2004 & 84.67 \\
\hline
\end{tabular}

Source: Datastream 


\section{Glossary}

ACOST Advisory Council on Science and Technology

ADB Asian Development Bank

AMT Advanced Manufacturing Technology

ARD American Research and Development

AVCJ Asian Venture Capital Journal

BPO Business Process Outsourcing

BVCA British Venture Capital Association

CAGR Cumulative annual growth rate

CBDT Central Board of Direct Taxes

CCPPO Cumulative convertible participating preferred ordinary share

CEO Chief Executive Officer

CVC Corporate venture capital

DCF Discounted cash flow

DFI Development finance institution

DTI Department for Trade and Industry

EBIT Earnings before interest and taxes

EBITDA Earnings before interest, taxes and/or before depreciation and amortization

EQ Emotional Quotient

ESOP Employee Stock Options Programme

EVCA European Venture Capital Association

FDI Foreign Direct Investment

GDP Gross Domestic Product

GEM Growth Equity Market

HBS Harvard Business School

HR Human resources

HRM Human resources management

ICICI Industrial Credit and Investment Corporation of India

IDBI Industrial Development Bank of India

IFCI Industrial Finance Corporation of India

IP Intellectual property

IPO Initial Public Offering

IQ Intelligence Quotient

IRR Internal rate of return

IT Information Technology 
ITMT IT, media and telecommunications

IVCA Indian Venture Capital Association

KLSE Kuala Lumpur Stock Exchange

LGS (Small Firms') Loan Guarantee Scheme

LP Limited partnership

MBA Master of Business Administration

MIT Massachusetts Institute of Technology

MoI Multiple of investment

NBFC Non-banking finance company

NEA New Enterprise Associates

NPL Non-performing loan

NPV Net present value

NRI Non-Resident Indian

NSE National Stock Exchange (of India)

OECD Organization for Economic Co-operation and Development

OTCEI Over The Counter Exchange of India

P\&L Profit and loss

PBUH Peace be Upon Him

PLS profit and loss sharing

R\&D Research and development

RBI Reserve Bank of India

SBA Small Business Administration

SBRC Small Business Research Centre (Cambridge University)

SEBI Securities and Exchange Board of India

SIDBI Small Industries Development Bank of India

SMEs Small and medium-sized enterprises

SOE State-owned enterprise

SPSS Statistical Package for Social Sciences

SQ Spiritual Quotient

SSIs Small scale industries

STPI Software Technology Parks of India

SVC Social venture capital

TDICI Technology Development and Information Company of India

TPIC Technology Policy Implementation Committee

TQM Total quality management

TTMM Two-Tier Mudarabah Model

USM Unlisted Securities Market

UTI Unit Trust of India

VC Venture capital

WIIG Walden International Investment Group 